Izabela LIS-WIELGOSZ*

Instytut Filologii

Słowiańskiej UAM

Poznań
Прегледни рад

Примљен: 07. 10. 2018.

Прихваћен: 03. 12. 2018.

\title{
СРПСКИ ЈЕЗИК, КЬИЖЕВНОСТ И КУЛТУРА У ОКВИРУ СЛАВИСТИЧКИХ СТУДИЈА НА ИНСТИТУТУ СЛОВЕНСКЕ ФИЛОЛОГИЈЕ УНИВЕРЗИТЕТА „АДАМ МИЦКЈЕВИЧ” У ПОЗНАҢУ
}

\footnotetext{
У раду се разматра српски језик, књижевност и култура у оквиру славистичких студија на Институту за словенску филологију Универзитета „Адам Мицкјевич” у Познању. Овде се приказује историја и традиција, а такође и савремено стање славистичких (посебно и србистичких) студија у познањској научној средини.

Кључне речи: славистика, студије, српски језик, српска књижевност, српска култура, историја, традиција, савременост.
}

Институт за словенску филологију (од 2008. године до данас) Универзитета „Адам Мицкјевич” у Познању, раније Катедра за словенску филологију (1988-2008), дуги низ година спроводи истраживања из области српскога језика, књижевности, културе и фолклора, а паралелно с тим у наведеним подручјима образује студенте и спроводи популаризацијску мисију на државном и међународном нивоу. Садашњи институт је највећи пољски славистички центар активног развоја у којем србистика има утврђено место, представља важну компоненту славистичких студија и практикује се уз помоћ разноврсног методолошког инструментарија у духу неговања традиције, али и модерне хуманистике. Познањска научна средина се може похвалити многим успесима на србистичком научно-наставном пољу, почевши од образовања многих генерација србиста, развоја властитог кадра, све до богатог корпуса монографских публикација и чланака у зборницима, престижним часописима итд. Познањска славистичка школа, чији важан део представља срби-

*izalisek@o2.pl 
стички кадар, данас се сматра истакнутим и угледним центром истраживача и стручњака. Ипак, пут до достизања таквог положаја није био лак, као што је уосталом случај са читавом славистиком у Пољској, која је настала и развијала се у различитим, повољнијим и мање повољним условима. Стога, требало би уопштено и у кратким цртама скицирати историјат познањских славистичких студија, а у оквиру њих и србистичких проучавања.

Важну улогу у иницирању и развијању славистичких истраживања у Познању одиграла је група лингвиста окупљених око организације познате као Познањско друштво пријатеља науке (Poznańskie Towarzystwo Przyjaciół Nauk), основане 1857. године. Ова организација до данас активно ради окупљајући око себе научнике из целе Пољске, у својој библиотеци корисницима омогућује приступ хиљадама научних радова и књижевних дела, а у оквиру властите издавачке куће објављује бројне значајне студије, укључујући и славистичке. ${ }^{1}$ Започета 1857 . године, делатност Друштва била је изузетно драгоцена, иако је у области саме славистике била видљива изражена диспропорција међу лингвистичком и књижевнонаучном активношћу, што је, између осталих, наглашавала Марија Бобровњицка, указујући на тадашњи недостатак самосталности и маргиналну позицију словенске науке о књижевности (Bobrownicka 1973: 30).

Ту је ситуацију 1919. године променило оснивање Познањског универзитета, преименованог 1955. године у Универзитет „Адам Мицкјевич” у Познању, што је допринело развоју пољске филологије и словенске филологије која се у њеном окружењу формирала. Импулс за шира славистичка истраживања у Познању било је оснивање Западнословенског института 1920. године, на чије чело стаје Миколај Рудњицки. Научни часопис тога института био је годишњак „Slavia Occidentalis”, у којем су се углавном објављивали лингвистички радови у вези са тематиком лехитске антике, полапског, померанијског итд. (в. нпр. Kuraszkiewicz 1973: 501). Часопис излази и данас, а радови који се у њему објављују тичу се пре свега проблематике западнословенских језика, али се појављују и чланци који се баве јужнословенском тематиком.

Једно време су познањска славистичка истраживања имала углавном лингвистички карактер, што потврђују реализовани научни пројекти на првој Катедри за словенску филологију Познањског универзитета, којом су према следећем редоследу управљали Тадеуш Лер-Сплавињски, Хенрик Улашина и Јан Отрембски. Ипак, постепено је расло интересовање и за словенске књижевности, што је нашло одраза у студијама познањских полониста као што су Станислав Добжицки и Тадеуш Грабовски (в. нпр. Maciejewski 1992: 60).

Развој познањске славистике привремено зауставља нацистичка окупација, Познањски универзитет бива затворен, а професори ухапшени или депортовани у Генерално губернаторство.

Након Другог светског рата славистичка истраживања се настављају у новом ритму, развијају се како у лингвистичком смеру тако и у смеру на-

\footnotetext{
${ }^{1}$ B. http://poznan.wikia.com/wiki/Poznańskie_Towarzystwo_Przyjaciół_Nauk
} 
уке о књижевности обухватајући све шири словенски простор. Руководство Катедре за словенску филологију поверено је 1950. године Владиславу Курашкјевичу, који је заједно с ученицима Лешеком Мошињским и Тадеушем Зданцевичем у лингвистичка истраживања увео источнословенску проблематику. Управо се тада, након ратних превирања, интегрисала познањска славистичка лингвистичка средина. На посао се вратио Миколај Рудњицки, појавили су се млади лингвисти: Лудвик Заброцки, Зенон Собјерајски, Јан Отрембски, Станислав Урбањчик, Владислав Курашкјевич и др. Убрзо су запослени и Лешек Мошињски, Зигмунт Загорски, Карол Зирхофер и Тадеуш Зданцевич, који врло брзо постају највећи ауторитети у области пољске и словенске лингвистике.

У послератном периоду на Познањском универзитету, као и уосталом у целој Пољској, у славистици заправо доминира лингвистика, мада се и пред словенском науком о књижевности отварају све повољније развојне перспективе. У том погледу се Познањ тада налазио у вероватно најповољнијој прилици у Пољској. Док је књижевнонаучна славистика, према мишљењу Марије Бобровњицке, „након Другог светског рата стартовала са готово нулте тачке" (Bobrownicka 1973: 13; в. Lehr-Spławiński 1955: 8; Jakóbiec 1951: 61-83), на Познањском универзитету је тада деловао најозбиљнији истраживач у подручју славистике - Вртел-Вјерчињски.

Године 1949. на Факултету за хуманистичке науке Познањског универзитета настаје Катедра за западнословенске књижевности, преименована 1952. године у Катедру за словенске књижевности, коју преузима Вртел-Вјерчињски. Филолошка школа Вртела-Вјерчињског постала је полазна тачка за научну делатност Ирене Квилецке и Јозефа Магнушевског, чији значајан допринос има удела у стварању канона тадашње славистике, али и појашњава парадокс прекинутог континуитета који је био толико изражен да су остварења Вртела-Вјерчињског увелико доказала неопходност постојања центра за западнословенска истраживања у Познању.

Након смрти Вртела-Вјерчињског, 1964. године управник Катедре за словенске књижевности био је краће време Владислав Курашкјевич, да би на крају њено руководство преузела Халина Пањчик, којој је поверена мисија организовања русистичких студија (в. Pańczyk 1977: 9, 198). Неколико година касније у оквиру реструктурацијских промена Катедра за словенске књижевности бива повезана с Катедром за руску филологију, а потом у оквиру Института за руску филологију добија назив Одсек за словенске језике и књижевности. Упркос званичним декларацијама о развоју словенске филологије, стварна добит дате реструктурације била је руска филологија. Отворено је, додуше, неколико нових славистичких радних места, али су западнословенска и јужнословенска филологија, чији су представници били лекторати, практично биле једина словенска средина у окружењу организацијски, идеолошки и финансијски привилеговане русистике.

Истраживања Одсека за словенске језике и књижевности била су фокусирана на следећа питања: бугарски модернизам у односу на француска и руска надахнућа и бугарско-пољске и пољско-руске паралеле (Халина 
Пањчик); улога пољских модерниста у књижевном животу Бугарске (Богдан Крупски); бугарска поезија друге половине XX века (Хана Долата); теорија превођења и поезија Г. Аполинера у оквиру чешке поезије (Барбара Митко Шик); словачки модернизам и натуралистичке тенденције у словачкој прози (Ева Крашевска); књижевност Босне и Херцеговине у међуратном периоду (Александра Станкович); проза Иве Андрића, митови и идеје српске прозе XIX и XX века (Богуслав Зјелињски).

И поред покушаја стварања платформе за проучавање јужне и западне славистике упоредиве с трима славистичким институцијама које су тада постојале (Варшава, Краков и Сосновјец), ситуација је била све тежа. Познањска славистика је платила цену ранијих кадровских немарности губећи истраживачки, генерацијски и институционални ток, што је било везано за доношење одлуке о развоју русистике и одустајање од напора у корист западне и јужне славистике. Невелики Одсек за словенске језике и књижевности на Универзитету „Адам Мицкјевич” у Познању је изводио само изборну наставу за студенте руске филологије.

Прекретницу је представљало осамостаљивање Одсека за словенске језике и књижевности, његово трансформисање у Катедру за словенску филологију и пребацивање катедре на новоосновани Факултет за пољску и класичну филологију 1988. године.

Током 1988-1996. године Катедром за словенску филологију управља Тадеуш Зданцевич, а током 1996-1999. године Богдан Валчак, да би 1999. године управник катедре, а након тога и директор Института за словенску филологију (од 2008. године), постао Богуслав Зјелињски, који и данас њиме управља.

Од тренутка када Богуслав Зјелињски преузима руководство, долази до динамичних промена у развоју познањског славистичког центра, развијају се јужнословенска, западнословенска и балканолошка истраживања, која прати и разрађена дидактичка понуда, а заједно с њима долази до ширења научно-наставног кадра. Тако су у оквиру Катедре установљене студије из области бугарске филологије (1989/1990), српске филологије (1991/1992), хрватске филологије (1992/1993), а затим су настале двопредметне пољско-славистичке студије (1999/2000), чешка филологија (2012/2013) и јужнословенске студије (2016/2017), за које се показује велико интересовање.

Познањски славистички центар је започео, развијао и наставља да спроводи истраживања у оквиру следећих научних области и проблема²:

1) интеркултурне студије из области словенских језика и књижевности, компаративна проучавања, као и етнокултурна истраживања јужнословенског и западнословенског идентитета, која су довела до конституисања познањске славистичке школе, усмерене на питање перцепције заједнице из неконфронтативне перспективе четири Славије: Slaviae Latinae, Slaviae Orthodoxae, Slaviae Islamicae и

\footnotetext{
${ }^{2}$ У овоме раду - у литератури - су као илустрација наведене одабране монографије, док је увид у потпуну библиографију могући на интернет страници Института: http://slavic.home.amu.edu.pl/
} 
Slaviae Judaicae; разматрање различитих образаца културне и националне идентификације западног и јужног словенског културног круга у трансформацијском и посттрансформацијском периоду, које обухвата актуализацију и редефиницију актуелне западнословенске и јужнословенске културне аутоперцепције у феноменолошком и системском смислу, указује на функционализацију и семантику њихових кључних етнокултурних идеја и узима у обзир релације према балканском окружењу, Средњој Европи и Западној Европи;

2) проучавања проблематике савремених методолошких теорија и емпиријских истраживања усмерених на проблеме трансформације и ревалоризације културних кругова, картографисања културе и на проблематику територијалног аспекта промена у идентитету књижевности и култура Средње Европе и Балканског полуострва;

3) истраживања из области савремене западнословенске и јужнословенске науке о књижевности смештене у оквире структуралне и херменеутичко-феноменолошке мисли, тематологије и аутобиографизма, постструктурализма, деконструкције и Culture Studies; студије из области западнословенске и јужнословенске науке о књижевности у типолошком, компаратистичком и конфронтативном смислу, које се концентришу на проучавање бугарске, чешке, хрватске и српске поезије и прозе XIX и XX века, али и авангардних токова хрватске, српске и чешке књижевности XX века;

4) студије посвећене развојним процесима савремених западнословенских и јужнословенских језика у светлу социополитичких и културних промена; истраживања која обухватају следеће теме: анализа диференцијације савременог чешког језика у односу на друге западнословенске језике и сличних појава у јужнословенским језицима; распознавање промена које се дешавају како у савременом чешком, словачком, горњолужичко- и доњолужичкосрпском тако и у јужнословенским језицима;

5) феноменолошка и семиотичка разматрања духовног и идејног простора Slaviae Orthodoxae као источнохришћанског културног модела и средњовековних система православних словенских култура који су с њим повезани; културолошка истраживања везана за коегзистирање латинске и православне традиције; истраживања на граници историје уметности, културологије и филологије;

6) проучавање јужнословенског фолклора; истраживања словенског фолклора као наднационалног кода, која су наставак разматрања територијалних, националних показатеља, показатеља на нивоу заједнице и форми балканског фолклора, његове словенске и несловенске компоненте, проучавање балканске књижевности из перспективе класификације и генологије;

7) родне студије посвећене јужнословенским културама и књижевностима XIX, XX и XXI века; разматрање друштвено-културног рода у јужнословенским књижевностима и културама: бугарске, маке- 
донске, српске и бошњачке, као и дијагностиковање и дефинисање појава везаних за gender studies.

У оквиру Института за словенску филологију Универзитета „Адам Мицкјевич” тренутно функционишу следећи одсеци: Одсек за јужнословенске књижевности, Одсек за западнословенске језике и књижевности, Одсек за славистичку културологију, Катедра за родне и транскултурне балканолошке студије (од 2013. године), а такође и два лингвистичка одсека: Одсек за компаративну лингвистику и Одсек за јужнословенске језике. Неопходно је нагласити да напред представљена поља истраживања Института превазилазе, што је природно и пожељно, организацијске оквире наведених одсека.

На Институту за словенску филологију спроводе се бројна и разноврсна научна истраживања која обухватају западнословенски, средњоевропски, јужнословенски и балкански простор. Интердисциплинарне студије познањских слависта приказују западнословенско и јужнословенско подручје, Средњу Европу и Балканско полуострво као просторе који обухватају много култура, језика и књижевности, традиција, конфесија и огромно народно благо, не изостављајући притом и изванредно савремено позориште и кинематографију који су врло популарни код публике и критичара.

У том широком, разноврсном интердисциплинарном научном току налази се и србистика, која се једнако као и остале филолошке студије познањског центра, практикује уз помоћ савремених научних метода и развија на терену вишегодишње славистичке традиције, а истовремено се непрестано прилагођава најновијим научним достигнућима и изазовима савремене културне, друштвене, геополитичке, религијске стварности итд. Србистика као одељак славистике који се бави проучавањем српског језика, књижевности, културе и фолклора, на Институту за словенску филологију Универзитета „Адам Мицкјевич” представља важан и динамичан простор научног разматрања. Већ дуги низ година развој академске славистике у Познању прате различита наставна, популаризацијска и промотивна активност на градском, државном и међународном нивоу.

Србистичка истраживања у познањском славистичком центру у својој основи обухватају српски језик, књижевност, културу и фолклор, међутим, веома често она престављају део већих славистичких пројеката компаратистичког карактера. У сферу интересовања познањских србиста улази низ кључних проблема и разноврсних феномена у вези са српским језиком, књижевношћу и културом.

Србистичка истраживања на Институту за словенску филологију Универзитета „Адам Мицкјевич” у Познању развијају се унутар интердисциплинарних токова, при чему се посебно води рачуна о методологији науке о књижевности, лингвистике, културологије и транслатологије. Истраживачко поље обухвата све развојне епохе српског језика, књижевности и културе, а научна истраживања се врше у оквиру појединачних или групних пројеката.

У монографској студији посвећеној српском историјском роману Богуслав Зјелињски на широком књижевном, културном и историјском пољу 
представља улогу ове књижевне врсте у широко схваћеном процесу обликовања и петрификације националне идеологије и националних митова. У истраживачком пољу аутора налазе се и косовски мит, српска и црногорска проза XX века, разматране превасходно из перспективе конструисања књижевног канона, интертекстуалне и културне релације између Средње Европе и Балканског полуострва и митографска и постколонијална критика.

Истраживања која је Богуслав Зјелињски започео у вези с геокултурном мапом словенског простора омогућила су да се србистичка разматрања уграде у шири пројекат који обухвата проблематику преображаја и ревалоризације културних кругова, картографисања културе и територијалне/регионалне аспекте идентитета књижевности и култура Средње Европе и Балканског полуострва. На тај начин се у сфери разматрања нашла и српска култура у контексту региона сагледаног кроз призму проблемских области из сфере геопоетике, имагинарне географије, територијалне имагологије, у оквиру такозваног просторног/топографског обрта.

Данко Шипка је у Институту за словенску филологију Универзитета „Адам Мицкјевич” радио на развоју савремене јужнословенске лингвистике, укључујући и српску. Његово интересовање за српски језик резултирало je бројним монографским и речничким публикацијама. Истраживања српског језика се настављају и углавном су компаративног карактера. Тичу се проучавања језика у, на пример, пољским, српским и хрватским медијима, заснована на компаративној анализи језика у електронским и штампаним јужнословенским медијима из угла описа најважнијих промена које се дешавају у медијском дискурсу, посебно у начину коришћења социотехника манипулације. Србистичка лингвистичка истраживања имају примену не само у оквиру академске наставе већ су од важности и за развој словенске лингвистике, теорије и технике превођења итд.

У познањском центру развијају се и србистичка медијевистичка истраживања која чине важан део научних разматрања истраживача књижевности с Института за словенску филологију (што треба сматрати његовом посебном цртом на подручју целокупне пољске славистике). Она се тичу читавог простора Slaviae Orthodoxae, а једнако је важно, непосредно и посредно разматрано, питање функционисања словенских православних култура у односу на општи - источнохришћански, византијски културни модел, као и њихово повезивање с културним системима простора Slaviae Latinae. Суштинско истраживачко поље представља ипак културни простор Slaviae Orthodoxae у њеним макро и микро димензијама, а разматрања познањских медијевиста тичу се углавном византијског модела и словенских средњовековних православних култура које унутар њега постоје или пак функционишу у складу с њим: бугарске, српске, русинске и руске.

Централно поље истраживања Изабеле Лис Вјелгош чини српски средњи век, а у новије време његова последња развојна фаза (XVI и XVII в.), схваћена као један од основних носилаца симболичког и традиционалног (традиционалистичког) система културе. Публикације ове ауторке из наведене области углавном презентују српску књижевност седамнаестог века у 
контексту њеног развоја и функционисања, традиционалних врста које у оквиру ње постоје, средњовековних наративних стратегија, доминантних идејних образаца, идеолошких конструкција, репрезентацијских схема итд.

Научна истраживања Павела Ђадула усмерена су на српску књижевност и културу из перспективе универзалних идеја, а у најновије време се у центру његовог интересовања налазе период деспотовине и почеци османлијског периода. Његова проучавања имају за циљ детектовање модификација симболичко-идејне сфере које су кључне за тај период и чија анализа омогућава разумевање како унутрашњих трансформација српског симболичког универзума тако и његовог односа према претећем алтернативном универзуму (модел османлијске културе).

Научна интересовања Доминике Гапске тичу се улоге жена у оквиру традиције српског православља у културном (превасходно у подручју књижевности), историјском и религијском погледу. Ауторка анализира феномен светости жена у Српској православној цркви из функционалног аспекта, распознаје женске култове на основу анализе обредне књижевности (литургијске): хагиографије, еухографије (молитви) и химнографије.

Србистичка истраживања су усмерена на културу и широко схваћену духовност простора Slaviae Orthodoxae (старосрпска, старобугарска и староруска култура), уз узимање у обзир филозофскоисторијских доктрина, политичке теологије, есхатолошких идеја и самоидентификацијских теорија. У сфери научних интересовања налази се и екуменски дијалог између католичке и православне цркве и међукултурни односи Пољске, Балкана, Русије и Украјине кроз историју.

Значајно проширење познањских србистичких истраживања представљају разматрања јужнословенског фолклора који се шире посматра као међукултурни код. Истраживања из ове области су утолико важнија јер, треба нагласити, својеврсни парадокс савремене пољске академске јужне славистике јесте изостављање или маргинализовање капиталног културног и идентитетског феномена какав је фолклор, како у научној пракси тако и у наставној активности. Институт за словенску филологију један је од малобројних центара који ради на развоју истраживања из области фолклора у ширем смислу, која обухватају и духовну и материјалну културу.

Јоана Ренкас је најпре разматрала обредно-обичајне аспекте српске традиционалне свадбе и њеног израза у лирици и епици, да би потом проширила поље својих интересовања анализирајући хришћанску парадигму српске традиционалне обредности и обичаја који прате рођење, као и магичне формуле које су с њим повезане. Тренутно је предмет научних истраживања Јоане Ренкас календарска обредност приказана на материјалу обредно-обичајног комплекса Водица - једног од најпопуларнијих празника у Македонији (пре свега западној), који је познат под званичним црквеним именима као што су Богојављење, Епифанија или Исусово крштење на реци Јордану.

У оквиру познањских србистичких истраживања налазе се и транскултурна и родна проучавања. Магдалена Кох се бави историјом српске, хрватске и бошњачке књижевности XX и XXI века, родним студијама, културном 
историјом жена, феминистичком критиком, српским феминистичким есејом и др.

Развоју србистичких истраживања иду у прилог и научна путовања запослених и учествовање у домаћим и међународним конференцијама које организује и Институт за словенску филологију. Функција научних сусрета није само објављивање резултата индивидуалних истраживања или групних пројеката већ и шира промоција српског језика, културе, књижевности и фолклора; они често представљају платформу за дискусију о значајним проблемима и изазовима савременог света. Последњих година је у познањском центру одржано више научних сусрета међународног карактера за која су интересовање показали не само академско већ и шире универзитетско окружење; од организованих конференција, панела и дискусија издвајамо следеће: Балкански фолклор као међукултурни код; Слика светости-светост у слиии; Транскултурне, транснационалне, трансдисииплинарне перспективе женске књижевности; Преписивање, разноликост и прожимање култура или словенска вавилонска кула. Преводи, кореспонденција, узајамни утицаји; Пејзаж након трансформаиије. Conspectus Permutationum и отворена дебата Национални језищи Средње и Јужне Европе: глобализаџија, идеологија, идентитет и друге.

Важну област србистичке активности на Институту за словенску филологију чини наставна активност, чију основу представљају лекторат српског језика који воде изворни говорници ${ }^{3}$ и обилан корпус обавезних и изборних предмета из области језика, књижевности, културе и српског фолклора. Програм студија обухвата и специјализације у оквиру којих студенти - будући србисти, развијају компетенције у подручју теорије превода, културологије и туризмологије. ${ }^{4}$ Српски језик, култура и фолклор чине језгро студија у области српске филологије, али представљају и важну компоненту балканолошких студија код којих се акценат ставља на међукултурну комуникацију, културне, историјске, друштвене и политичке односе и зависности на Балкану за чије је проучавање погодна интегрисана настава, али и разноврстан корпус лекторских вежби чија понуда осим наставе једног словенског језика (српског, хрватског или бугарског) обухвата и наставу несловенског језика (румунског, албанског или турског).

Важна компонента студија српске филологије јесте упознавање српског језика и културе кроз посете Србији (Београду, Новом Саду, Нишу, Крагујевцу) у оквиру стипендија и истраживачких пракси, програма мобилности MOST, Erasmus i CEEPUS, али и у оквиру индивидуално организованих пројеката.

Студенти имају могућност учествовања у многим културним догађајима које организује Институт за словенску филологију у Познању. Неки од њих

\footnotetext{
${ }^{3}$ На Институту за словенску филологију Универзитета „Адам Мицкјевич” лектори за српски језик били су: Љубица Росић, Станислава Костић, Павле ћосић, Слободан Владушић, Владимир Гвозден, Ана Костек, Слађана Јанковић, Јелена Јовановић, а тренутно лекторске вежбе води Ана Самарџић.

${ }^{4}$ Програм студија је доступан на интернет страници Института: http://slavic.home.amu.edu.pl/
} 
cy: I Balkan Film Fest, Недеља српског филма: На ивици; III Балкански дани (гост је, између осталих, био и писац Бора Ћосић); Хуманистичке радионице: Шта ти знаш о словенству? Сусрет 1 (заједно с предавањима нпр. Маје Миличевић и Бојане Субашић из Завода за проучавање културног развитка Републике Србије); Дани српске културе; Poznań Slavic Fest; III Balkan Urban Film Fest; Poznań Slavic Fest; Cafe Europa (поред других, учествовали су и Радослав Петковић, Милета Продановић, Ненад Величковић); И после Тита - Тито; Партизанско поподне (сусрет с Магдаленом Богуславском, ауторком књиге под насловом Слика власти у власти слике); Постјугословенска драма и позориште. Транскултуралност, модел мреже, културна дипломатија (сусрет с Габријелом Абрасович) итд.

Србистичка и шире славистичка научна и образовна делатност познањског центра почивају и на узајамним контактима и посетама, сусретима с еминентним гостима из Србије. На Институту за словенску филологију предавања су, између осталих, одржали и Александар Јерков Шта је европско у српској књижевној имагинаиији данас; Бошко Сувајџић Иво Андрић и народна књижсевност; Александар Јерков Сусрет у Андрићу - писаи и његово дело с ону страну хибридног идентитета; Божидар Језерник Зашто је Мештровићев победник на Калемегдану - го? Кристијан Прунич Преглед лужичкосрпске културе; Биљана Дојчиновић Дигитализачија и (ра)стварање канона: Књиженство, теорија и историја женске књижевности на српском језику; Ђорђе Деспић Поезија и традииија: Поезија Миодрага Павловића и савремена српска поезија; Дубравка Ђурић Савремено српско песништво између модернизма и анти-модернизма и други.

У закључку треба нагласити да србистичка истраживања у оквиру Института за словенску филологију представљају интегрални део славистичких научних проучавања, а њихови резултати видљиви су на неколико нивоа - научном, наставном и популаризацијском.

Славистичка активност (укључујући и србистичку) у својим хипотезама, циљевима и резултатима кореспондира са стратегијом развоја Факултета за пољску и класичну филологију и Универзитета „Адам Мицкјевич” у Познању, која подразумева бригу о највишем квалитету истраживања, ефикасности научних активности, друштвеној употребљивости и ширењу знања. Научна истраживања института формирају компактан приказ филолошких и хуманистичких дисциплина које чине полонистика (национална филологија), класична филологија (древна основа европске и пољске културе) и словенска филологија као најближе етнокултурно и географско окружење. Филолошко језгро научних проучавања која се спроводе на Факултету, заснована на повезивању филолошког знања с културолошком и антрополошком проблематиком и медијима, рефлектују модерни концепт савремене неофилологије, укључујући и славистику као интердисциплинарну науку о култури. Институт за словенску филологију се у научном окружењу сматра познањском славистичком школом која ради на етнокултурним истраживањима идентитета на јужнословенском и западнословенском подручју и филолошким и културолошким славистичким разматрањима. Мисао познањске славистичке 
школе везана је за питање перцепције заједнице из неконфронтативне перспективе четири Славије, а научни допринос у тој области представља важан, оригиналан и значајан допринос ангажованим савременим хуманистичким наукама.

На крају треба најавити да ће србистика, као важан и нераздвојиви део истраживања Института за словенску филологију, бити заступљена и представљена у оквиру прославе стогодишњице Универзитета „Адам Мицкјевич” у Познању (1919-2019), током које ће се одржати низ предавања и културних догађаја у циљу презентације и промоције вишегодишње традиције славистичких истраживања, а у оквиру њих и србистичких."

\section{ЛИТЕРАТУРА}

Bobrownicka 1973: M. Bobrownicka, 25 lat literaturoznawstwa zachodnio- $i$ potudniowostowiańskiego w Polsce Ludowej, „Slavia Occidentalis”, Poznań, $13-33$.

Dutkowski 1963: J. Dutkowski, Materiaty do bibliografii publikacji naukowych Stefana Vrtela-Wierczyńskiego, „Slavia Occidentalis”, t. 23, Poznań, 11-21.

Dziadul 2014: P. Dziadul, $W$ oczekiwaniu na Paruzję. Myśl eschatologiczna w prawosławnym piśmiennictwie stowiańskim do połowy XVI w., Kraków.

Gawarecka 2012: A. Gawarecka, Margines i centrum. Obecność form kultury popularnej w literaturze czeskiej dwudziestolecia międzywojennego, Poznań.

Grabowski 1963: T. S. Grabowski, Śp. Stefan Vrtel-Wierczyński. Jego działalność naukowa i bibliograficzna, „Slavia Occidentalis”, t. 23, Poznań, 5-10.

Grześ, Kozłowski, Kramski 1976: B. Grześ, J. Kozłowski, A. Kramski, Niemcy w Poznańskiem wobec polityki germanizacyjnej (1815-1920), Poznań.

Jakóbiec 1951: M. Jakóbiec, Stan i postulaty naukowe historii literatur stowiańskich w Polsce, „Pamiętnik Słowiański”, t. 2, Kraków, 61-83.

Jóźwiak 2017: W. Jóźwiak, Obraz poczatku i końca średniowiecznego państwa w butgarskiej powieści historycznej z lat 1874-1989, Poznań.

Koch 2012: M. Koch, ...kada sazremo kao kultura... Stvaralaštvo srpskih spisateljica na početku XX veka (kanon-žanr-rod), Službeni glasnik, Beograd.

Kuczyńska 2003: M. Kuczyńska, Poludniowosłowiańska poezja liturgiczna w zbiorach bibliotek polskich, Szczecin.

Kuczyńska 2004: M. Kuczyńska, Homiletyka ruska XVII wieku. Ewolucja gatun$k u$ - Specyfika funkcjonalna, Szczecin.

Kuczyńska 2011: M. Kuczyńska, Z Zachodu na Wschód. Obywatele Rzeczypospolitej na ottarzach Cerkwi rosyjskiej, Kraków.

Kuraszkiewicz 1973: W. Kuraszkiewicz, Językoznawstwo polskie i stowiańskie na Uniwersytecie Poznańskim (1919-1969), y: Nauka w Wielkopolsce. Przeszłość i teraźniejszość. Studia i materiały, yp. G. Labudy, Poznań.

\footnotetext{
* На српски језик превела Ана Самарџић.
} 
Lehr-Spławiński 1955: T. Lehr-Spławiński, Dziesięciolecie slawistyki Polski Ludowej, „Pamiętnik Słowiański”, t. 5, Kraków, 3-19.

Lis 2003: I. Lis, Śmierć w literaturze staroserbskiej (XII-XIV w.), Poznań.

Lis-Wielgosz 2005: I. Lis-Wielgosz, Święci w kulturze duchowej i ideologii Stowian prawosławnych $w$ średniowieczu do $X V$ w., Kraków.

Lis-Wielgosz 2013: I. Lis-Wielgosz, O trwałości znaczeń. Siedemnastowieczna literatura serbska w stużbie tradycji, Poznań.

Maciejewski 1992: B. J. Maciejewski, Dzieje Poznańskiej polonistyki uniwersyteckiej 1842-1988, прир. T. Lewandowski, Poznań.

Pańczyk 1977: H. Pańczyk, 10 lat filologii rosyjskiej w Uniwersytecie im. Adama Mickiewicza w Poznaniu (1965-1975), „Studia Rossica Posnaniensia”, 9, Poznań, 197-214.

Pańczyk 1983: H. Pańczyk, Problematyka badań nad literaturami zachodnio- $i$ poludniowostowiańskimi w UAM w 35-leciu PRL, ,Studia Rossica Posnaniensia", 17, Poznań, 173-186.

Pieniążek 2000: K. Pieniążek, Twórczość poetycka Antuna Branka Šimicia, Poznań.

Pieniążek 2011: K. Pieniążek-Marković, ,Ja” - czlowiek i świat w najnowszej poezji chorwackiej (1990-2010), Poznań.

Prałat 2013: E. Prałat, Slavia Graeco-Romana. Na pograniczu tekstu i obrazu-o iluminacjach rękopisów staro potudniowostowiańskich (XII-XIV w.), Poznań.

Rękas 2011: J. Rękas (ред.), Bałkański folklor jako kod interkulturowy, Poznań.

Rękas 2005: J. Rękas, Obrzędowo-obyczajowy kompleks serbskiego tradycyjnego wesela i jego werbalne manifestacje, Poznań.

Rękas 2010: J. Rękas, Narodziny. Rzecz o serbskiej obrzędowości i literaturze serbskiej ludowej, Poznań.

Rękas 2018: J. Rękas, Między stowami. Projektowanie folklorystyki konwersacyjnej na materiale Wodzic w Macedonii, Poznań.

Wojtkowski 1929: A. Wojtkowski, $Z$ dziejów stosunków Poznania do zagadnień stowiańskich w wieku XIX, y: „Kronika Miasta Poznania”, 7, 195-206.

Zagórski 1973: Z. Zagórski, Zarys rozwoju językoznawstwa polskiego w Wielkopolsce (do r. 1918), y: Nauka w Wielkopolsce. Przeszłość i teraźniejszość. Studia i materiaty, yp. G. Labudy, Poznan, 473-498.

Zekić 2016: M. Zekić, Muslimanski odgovor izazovima Okcidenta. Islamizacija Zapada ili vesternizacija islamskoga svijeta. S posebnim osvrtom na Bosnu i Hercegovinu i bosanskohercegovačke muslimane - Bošnjake, Poznań.

Zieliński 1998: B. Zieliński, Serbska powieść historyczna. Studia nad źródtami, ideami i kierunkami rozwoju, Poznań.

Zieliński 2002: В. Zieliński (ред.), Narodowy i ponadnarodowy model kultury. Europa Środkowa i Pótwysep Batkański, Poznań.

Zieliński 2002: В. Zieliński (ред.), Wokół Macedonii: siła kultury - kultura sity, Poznań.

Zieliński 2003: В. Zieliński (ред.), Macedonian Issue: the Power of Culture, the Culture of Power, Poznan. 
Zieliński 2008: B. Zieliński (ред.), Tradycje pogranicza i przestrzenie tradycji. Od komunizmu do postmodernizmu i postkolonializmu. Tom dedykowany XIV Kongresowi Slawistów (Ochryda 10-17. IX 2008 roku), Poznań.

Zieliński 2013: В. Zieliński (ред.), Przestrzenne kody tekstów i narracyjne kody przestrzeni, yp. B. Zieliński, Poznań.

Zieliński, Firlej, Jóźwiak 2012: B. Zieliński; A. Firlej, W. Jóźwiak (ред.), Тороgrafia tożsamości, t. 1, 2, Poznań.

Симеонова-Конах 2011: Г. Симеонова-Конах, Постмодернизмът - българският случай. Наблюдения върху художествената проза ХХ и ХХІ век. Издателство Изток-Запад, София.

Izabela Lis-Wielgosz

SERBIAN LANGUAGE, LITERATURE AND CULTURE IN SLAVONIC STUDIES CONDUCTED IN THE INSTITUTE OF SLAVONIC PHILOLOGY AT THE UNIVERSITY OF ADAM MICKIEWICZ IN POZNAŃ

Sum mary

The article is of a review descriptive character, and is a presentation of Slavonic research conducted in the Institute of Slavonic Philology at the University of Adam Mickiewicz in Poznań. An essential part of the exposition regards its historical view namely, a chronological presentation of the development of Slavonic studies with emphasis on Serbian studies in Poznań scientific-research centre. It also assumes a necessity of outlining directions and fields of progression in order to illuminate a complicated context of formation of this branch of science which is identified with Slavonic philology concentrated on research dedicated to Slavic languages, literatures and folklore. The historical introduction above all serves a presentation of the current state of Slavonic (including Serbian) research conducted in Poznań centre, which regards West and South Slavonic, Central European, and Balkan area. Studies carried out by the Institute are concentrated on the problems of contemporary methodological theories and empirical explorations related with the issues of transformation and revaluation of cultural circles, cultural cartography, and territorial aspect of changes shaping identity of literatures and cultures of Central Europe and Balkan Peninsula; they are located in the realm of West and South Slavonic literary studies, and draw from devices elaborated by structuralism, hermeneutics, phenomenology, thematic studies, autobiographical discourse, poststructuralism, deconstruction, Culture Studies; the conducted studies concern development processes of West and South Slavonic contemporary languages in the light of social-political and cultural transformations; they also refer to the spiritual and ideal space of Slaviae Orthodoxae as the Eastern Christian cultural model along with medieval systems of Slavonic Orthodox cultures; they assume an analysis of the problem of South Slavonic folklore as an international cultural code; they also inscribe in the gender reflection over cultures and literatures of South Slavs in the nineteenth, twentieth, and twenty-first century, including social and cultural gender in South Slavonic literatures and cultures. The third and last field of scientific reflection, elaborated in the Poznan centre and presented in the article, is Slavonic (above all Serbian) academic didactics and popularizing activity of the Institute of Slavonic Philology at the University of Adam Mickiewicz in Poznań. 